ISMC 2021

$16^{\text {th }}$ International Strategic Management Conference

\title{
FUNDING RESEARCH CERTIFICATION PROGRAMS IN THE SPHERE OF TOURISM
}

\author{
Nurkhodzha Akbulaev (a)* \\ *Corresponding author \\ (a) UNEC Turkish World Economic Research Center, \\ Azerbaijan State University of Economics (UNEC), Faculty of Economics of Turkish World \\ Department of Economics and Business Administration. Abbas Sahhat 45A. Baku. Azerbaijan., e-mail: \\ nurhodja_akbulayev@unec.edu.az; nurhoca@gmail.com
}

\begin{abstract}
Tourism is a dynamically developing branch of the national economy of both developed and developing countries, which, accordingly, have the necessary potential of recreational resources. One of the effective methods of branding of the territory (region) is outsourcing of foreign services of certification, standardization and Metrology, including in the field of tourism. In this regard, the issues of financing of certification, standardization and Metrology processes in the field of tourism are particularly relevant. It is worth noting that in the situation of developing countries, where the national system of voluntary certification is not always trusted by foreign investors, the most relevant analysis of the best practices of developed countries and the outsourcing of relevant services from specialized transnational corporations. In this study, we analyzed the certification programs in the field of tourism and their financing models, as well as clarified the role of outsourcing of foreign certification services, standardization and Metrology in the field of branding of the territory and developed recommendations for optimizing financial flows. The results of the study will be useful to the General scientific community around the world.
\end{abstract}

2357-1330 @ 2021 Published by European Publisher.

Keywords: Certification, financing program, tourism; outsourcing 


\section{Introduction}

The tourism sector is defined as the planned travels of the tourists outside their own countries in order to receive quality and economic tourism services. Providing the services offered to tourists in tourism in line with internationally accepted standards is of great importance in terms of service quality. One of the factors that increase the quality of service in tourism is the provision of tourist safety. The importance of service quality and tourist safety in tourism has been examined.

Even after the physical texture elements of tourism enterprises come to the establishment, the service concept, quality level, sensitivity of the enterprise in terms of cleanliness and hygiene are also evidence of the extent to which the payment can be received. Tourism businesses have to present such physical evidence from the beginning to the end of a trip. Obtaining a certificate should be an important strategy that tourism operators should evaluate by businesses that want to get a larger share from tourism. As a result of certification, it will be beneficial for tourism enterprises to embody and display the history, culture, geography, climate, cuisine, folklore and similar values of the country in which they operate, in the tourism promotion activities they will develop, in the exhibitions and organizations they will participate in, in terms of providing an effective competitive advantage (Yildirgan \& Zengin, 2014).

Now in Russia national and regional agencies on development of a system of certification of qualifications are already created. For example, for the organization of assessment and certification of tourist services in the Russian Federation the public State Council works. Activity of a system of assessment and certification of services in the field of tourism and service will be directed to the solution of problems of providing the sector with professional staff and to improvement of quality of services. Certification will allow to reveal the hidden problems of ensuring tourism and service by qualified personnel and to realize a number of the actions aimed at the development of a system of training in the sphere of tourism and service including the higher and secondary professional education, professional development and retraining of personnel. Financing of the above processes is also accompanied by problems of management and organization. In the researches conducted earlier by domestic and foreign authors models and algorithms of financing of programs of certification in the sphere of tourism and also some aspects of a role of programs of certification in economic development developed and developing countries are described. For specification ambiguous processes of certification and their financing, as the recommendation to the state institutions responsible for development of the sphere of tourism, the purpose of the real research was formulated.

Goods and services produced by businesses should be of a quality that satisfies customers. Standards have been developed to ensure the said quality. In order to gain the trust of customers and to gain competitive advantage, businesses need to certify their compliance with standards. The main purpose of this study is to investigate the certification and financing methods of enterprises operating in the tourism sector.

The aim of our research is to indicate the role of outsourcing of foreign certification, standardization and metrology services in the field of branding of the region and to develop recommendations on the optimization of financial flows in certification financing in the field of tourism.

The subject of the research is the financing models of certification programs in the field of tourism. 
As a research question:

- What are the financing models of certificate programs?

- Are the financing models sufficient?

- What are the certificate programs in the field of tourism?

\section{Review of Literature}

As an information and theoretical base were used statistics in the field of tourism thematic sites on the Internet, as well as works on certification in the field of tourism, domestic authors (articles indexed databases RSCI and approved by the RF HAC) and foreign authors (articles from journals indexed in databases Scopus).

Modern aspects of certification of services in the sphere of tourism were considered in Ogneva (2013), Punkoet al. (2018), Vetitnev and Savelieva (2014) formulated recommendations in the field of assessment of certification's programs. Gairbekov and Chaplaev $(2017,2018)$ confirmed a hypothesis of a role of outsourcing of services of certification as a factor of effective branding of the territory of the region. Larionova (2013) disclosed aspects of the organization of financial flows in the system of voluntary certification in tourism and service. Foreign researchers also conducted work on the considered subject. In particular Rome et al. (2006) confirmed efficiency of stable financing of certification of services in the field of tourism for the purpose of regional development. From Font's (2002) works we specified infrastructure aspects of financing of programs of certification in the sphere of tourism. Works Walas and Celuch (2014) allowed to understand better the process of financing of programs of certification from a position of the organization and management of these processes. Yumin Lew, Jeroen Singls, Gavin, Eddie Chi-Mang Hough, Carmen Eskansiano, Anthony Steyns in the works specify a role of the international programs of certification in processes of investment into the tourist industry.

\section{Methodology}

The study such General scientific research methods as methods of deduction and induction, comparative analysis, synthesis, the method of scientific review of the source base and the method of statistical observation are used. Secondary data were also used in this study based on literature research.

\section{Programs of Certification in the Sphere of Tourism}

The bodies for certification accredited in accordance with the established procedure and registered in Rosstandart, the main requirement to which is independence and competence (Panochkina, 2016), can carry out certification of tourist services. Subjects to certification in the sphere of tourism are: the enterprises rendering tourist and excursion services, performers of tourist and excursion services, processes of rendering tourist and excursion services, a quality management system of the organizations working in the sphere of tourism (Guliyeva, 2020). The main features of works on certification of tourist services follow from features of services (Statistics on Azerbaijan's foreign trade balance). It is possible to carry to them: impossibility of quantitative assessment; need application of expert and sociological estimates for studying of opinion of consumers on quality of service. According to GOST P 50646-2012 
"Services to the population. Terms and definitions", services in functional purpose are subdivided into material and welfare. Since January 01, 2018 in the territory of the Russian Federation the national GOST P 57519-2017 standard "Compliance assessment "Of the rule and the procedure of carrying out voluntary certification of services in the sphere of tourism" is entered. The present standard establishes rules and procedures of carrying out voluntary certification of services in the sphere of tourism in the systems of voluntary certification created according to the Federal law from December 27, 2002 No. 184-FZ "On technical regulation" and registered by federal executive authority on technical regulation according to GOST P 50.1.052-2005 of the Recommendation about the contents and a form of the documents submitted on registration of a system of voluntary certification. Provisions of the present standard are recommended to be used to bodies for certification at work on certification of services in the sphere of tourism for ensuring objectivity and reliability of results of certification.

Certification of services in the field of tourism is carried out according to 3 certification schemes (Table 1). Scheme 1 is used for tourism services, the quality of which is determined by the skill of a particular performer, for example, an excursion - guide, an instructor, a guide.

Table 1. Schemes used for certification of tourism services

\begin{tabular}{cccc}
\hline Scheme number & $\begin{array}{c}\text { Evaluation of service } \\
\text { delivery }\end{array}$ & Checking service results & $\begin{array}{c}\text { Inspection control of } \\
\text { certified services }\end{array}$ \\
\hline 1 & $\begin{array}{c}\text { Assessment of skills of } \\
\text { the service provider } \\
\text { Evaluation of service } \\
\text { delivery } \\
\text { Evaluation of the } \\
\text { organization (enterprise) }\end{array}$ & Checking service results & $\begin{array}{c}\text { Control of skill of the } \\
\text { service provider } \\
\text { Control of skill of the } \\
\text { service provider } \\
\text { Compliance control }\end{array}$ \\
\hline
\end{tabular}

Scheme 2 is used for services in the field of tourism, the quality and safety of which are due to the stability of the process of providing services, for example, for tourist services - services of tour operators, travel agents. At the same time, the tourist organization is issued a certificate confirming the provision of services for the formation, booking and sale of the tourist product (Sokhanvar, 2019). According to the scheme 3, the whole organization (enterprise) - executor of services is evaluated for compliance with the requirements of regulatory and technical documents. The scheme assesses the availability and functioning of the quality assurance system of services; organizational, legal, software, methodological, information and other support; the state of the material and technical base of the applicant, including the equipment of premises, equipment, consumables, etc.; conditions of operation of the tourist industry; the content of internal documentation; the level of service staff; stability of functioning of systems of maintenance and service, including a condition of material support; ensuring fire protection and the notification; observance of sanitary and hygienic rules and other conditions providing safe accommodation and highquality service of visitors; observance of the General and additional requirements to means of placement; existence and observance of requirements of normative and technical documents on processes of rendering services; security and stability of the service delivery process, training and competence of service providers. When carrying out certification under the scheme 3 , the format, category or type of enterprise providing services in the field of tourism can be confirmed, if it is provided by the relevant 
regulatory and technical documents, as well as documents of the voluntary certification system (Thano, 2015).

Also in the system of voluntary certification are the following international standards:

- ISO 9001-2008 (Quality Management System);

- ISO 9001-2015 (Quality Management System);

- ISO 14001-2004 (Environment Management System);

- ISO 14001-2015 (Environment Management System);

- OHSAS 18001-2007 (Occupational Health and Safety Management System);

- ISO 45001-2018 (Occupational Health and Safety Management System);

- ISO 27001-2013 (Information Security management System) (Tariq, 2015).

\section{Financial Models of Financing of Certification Programs}

There is a certain standard universal model of financing of programs' certification which is most widely used by developed and developing countries (Gladun \& Ivanova, 2017).

If to take as base the analysis of the mechanism of mutual actions of the participants of complete structure of assessment of quality in the field of professional education it is possible to allocate financial flows which appear in the course of cooperation of the appraisal centers and certification of quality of tourism, various expert methodical centers with federal and regional executive authorities, with consumers of tourist services and education (Gulyayeva, 2020). Certain sums of money which are listed in a non-cash form for performance of work, rendering services and in a size which provides interaction of various parts of a uniform independent system of quality assessment of professional education are called financial flows.

The study of this issue served as the basis for the thesis that as the basis of financial relations 1 (Figure 1) between the expert and methodological centers and the CSC are the remuneration for services that are able to reimburse the costs of the entire system of activities of expert and methodological centers. In turn, for the CSC, financial flows have the characteristic of output flows, due to the fact that they are the funds of the center, which are transferred for the services rendered. On the part of the expert and methodological center, financial flows have the characteristic of input flows, because they include cash. Between the CSC and the expert and methodological center, financial flows cover:

- means of payment for the cost of ordered valuation methods and techniques for assessing qualifications, which are calculated in accordance with the totality of the requirements of organizational and methodological documents adopted in this system;

- means of payment for the direct cost of work in the field of development of organizational and methodological documents;

- means to pay for the cost of work in the field of methodological support of personnel certification centers; - funds to pay for the cost of training and training of experts;

- means of payment of all expenses in the process of organization of audit of activity of CSC;

- means of payment for the cost of various specialized consulting services.

Financial interaction COSC and the expert and methodical centre take place according to the previously signed between them contracts (Babeshko \& Orlova, 2018). There are two main schemes of 
interaction between the CSC and expert and methodical centers in the field of tourism and service: information-methodical and subscriber support of the CSC; - payment according to the points of onetime contracts for the provision of a certain type of service (Khoshnevis Yazdi \& Khanalizadeh, 2017). Further, the center of assessment and certification of qualifications shall pay for the full range of services rendered by the expert and methodological center after their official adoption in accordance with the act of acceptance of the work performed. The services agreed upon by the qualification assessment and certification Centre can be paid for after the conclusion of a certain the contract in full or using the transfer of advance payments.

In accordance with the legislation of the Russian Federation, payment for work performed and services rendered is made by Bank transfer. At the same time, the obligations of the center for assessment and certification of qualifications to the expert and methodical center for payments for work and services can be considered fulfilled from the time when these funds were received on the account of this expert and methodical center. As far as the calculation of the cost of services provided by the expert-methodical center is justified, the basic organization checks. To assess the reliability of reporting and accounting, an external audit carried out by a third-party and independent audit company is used (Dincer et al., 2015). Between the Center of assessment and certification of qualifications and the base organization 2 financial flows are carried out on the basis of pre-concluded agreements between the organizations and such financial flows include: - means to pay the cost of all custom certificates, forms and various annexes to them; - means to pay for registration or any other services that would compensate for the system costs of the main organization for the registration of the center; - means to pay for the maintenance and maintenance of various information services of the General system, which are directly related to the work of the organization; - means to pay for the audit of the financial activities of the center from the main organization. The cost of the ordered forms of certification is calculated in full compliance with all the requirements of the preparation of organizational and methodological documents of the system of evaluation of the quality of vocational education calculate the cost of the ordered forms, which is a strictly defined part of the tariffs for evaluation and certification of qualifications for reimbursement of the entire system. A similar calculation of the cost of services in accordance with the provisions and requirements for the preparation of organizational and methodological documents of the integrated system of quality assessment of vocational education. The main organization carries out external audit and monitoring of all activities of the center, also controls the cost of services rendered and works performed under paid contracts with legal entities and individuals. Financial relations. Between the Center of assessment and certification of qualifications and participants of the certification procedure 3 financial relations are built on a reimbursable basis (Krynova, 2018). As participants of the certification procedure can be: - individuals who are citizens of the Russian Federation, foreign citizens and stateless persons (hereinafter - applicants); - educational organizations that have applied for services for the assessment and certification of their qualifications job seekers - graduates of educational institutions of professional education; - organizations or employers and individual entrepreneurs or legal persons who have applied for services for the assessment and certification of qualifications of applicants directly from the organization's employees and candidates for vacant positions in certain areas of activities; employment centers that have applied for the assessment and certification of qualifications of applicants 
such as unemployed citizens and migrant workers. Between the Center of assessment and certification of qualifications and participants of the certification procedure financial relations consist in receiving payments by the Center: - on carrying out inspection control; - on performance of works on certification and the subsequent issue of certificates; - on performance of any other works which are connected with process of carrying out certification, consultations, etc.

In addition, the Center of assessment and certification of qualifications receives funding from the sale of information, guidance and other materials. Applicant the Centre for the assessment and certification of qualifications all expenses are paid for carrying out the assessment and certification of qualifications in stages, regardless of the decision on the issuance or, on the contrary, non-issuance of the certificate. The same applicants who have received the certificate, the Center of assessment and certification of qualifications are paid, in turn, all the costs associated with the conduct and organization of inspection activities during the validity of the certificate. The center of assessment and certification of qualifications carries out the procedure of settlements with applicants for certification of qualifications in full compliance with the full range of regulatory documents of the system of quality assessment of vocational education. Financial relations between the Centre of the assessment and certification of qualifications and applicants in the certification of financial relations function according to the items and the requirements of the previously concluded business agreements. At the same time, the main organization controls the cost of services rendered and works performed under paid contracts with legal entities and individuals. Between the main organization 4 and the expert and methodical center financial flows cover: - means on payment of remuneration for the registration or other rendered services which refund system expenses; - means on payment of expenses of the main organization for carrying out competitive selections; - means on payment of expenses of the basic organization for registration of the center, maintaining and maintenance in current state of information services of all system of assessment of quality of professional education which are connected under the contract with activity of the Center; means on payment of expenses of the main organization for carrying out audit regarding activity of the center. Between the expert and methodical center and the Main organization the financial relations are based on the basis of the contracts which are previously signed by them. In full compliance to requirements of drawing up organizational and methodical documents of a system of assessment of quality of professional education perform calculation of cost of the rendered services. The main organization exercises control of activity of the expert and methodical center by means of monitoring and audit. Between the expert and methodical centers and other participants of system 5 financial flows consist in receiving payment by the expert and methodical center: - on rendering services in consultation; - on development of necessary organizational and methodical documents. Between the expert and methodical center and other participants systems the financial relationship are built up according to requirements and paragraphs of previously signed contracts. All participants of a complete system of quality assessment of professional education have to pay the services in the act of acceptance of the performed works rendered to the expert and methodical center after their acceptance. Payment on the performed works and the rendered services has to be made by bank transfer in full accordance with the legislation of the Russian Federation. Between the expert and methodical center, the Appraisal center and certifications of qualifications and executive authorities financial flows are carried out with execution by 
the expert and methodical center and the Appraisal center and certifications of qualifications of the tax liabilities. As the expert and methodical centers and the Appraisal centers and certifications of qualifications are created as NPOs are non-profit organizations, on the laws existing in the Russian Federation, the similar organizations can be engaged in business activity only in such measure in which such activity can answer the purpose of creation given the organization. Taxes on business activity for non-profit organizations taxes are estimated in the same order, as for the commercial organizations.

\section{Analysis of the Effectiveness of Financing Certification Programs}

For the analysis of efficiency of financing of certification programs we will use an indirect method of the analysis on a resultant indicator. As we know, a resultant indicator of efficiency of financing of certification programs is the volume of investment into the industry. Thus, using a method of comparative observation of indicators of capital investments over the developing and developed countries, it is possible to achieve a main objective of a research.

The largest investments in the tourism industry are the USA and China. Their total share of the indicator in the world (the sum of the first twenty countries in the ranking) is $41 \%$. As it is already known, more investments come to the sphere of economy, where the quality of products is not in doubt. From the review of scientific articles by Dredge and Jamal (2011), this is due to the trust in the results of certification by the international community.

However, the question arises as India, a developing country, with an investment rate of $\$ 41.6$ billion in 2017. that is $24 \%$ of the same index of the leader of the us rating, took the third position of the rating. Moreover, the highest growth rate of the indicator is observed in the period between 2005 and 2010 - 1.5 times. Accordingly, the growth rate in 2010 compared to 2005 was $50 \%$. The fact is that the service sector of India began to be certified by transnational corporations with experience and trust from foreign investors since 2003.

Similar experiences have been drawn from developing countries such as Turkey, Mexico and Ireland. Their share in the scale of the indicator of investments in the world tourism industry was in 2017, respectively $5.4 \%, 2.3 \%$ and $0.3 \%$. The highest growth rate of investment in the tourism industry is observed in the period between 2015 and 2016, This fact is also explained by the outsourcing of foreign certification services of multinational companies between 2013-2014.

It is necessary to add that the main offices of the multinational companies "Esdzhies Group", $\mathrm{GmbH}$,"Intertek Group" rendering services in the field of the international certification of the sphere of tourism are located in the cities of such developed countries as, the USA (the leader of the rating of investments in branch of tourism), China (the second place in rating), France (the fourth place in rating), Japan (the fifth place in rating), etc.

\section{Discussion}

The efficiency of financing of the sphere of tourism, in many respects depends on prestige and recognition of the subject who is carrying out certification of products. 
The study contains theoretical and practical results that can be recommended to public authorities responsible for the development of tourism in developing countries.

On the example of developed countries, such as the USA, China, France, Japan, we confirmed that the activity of transnational companies in the field of certification of tourist services affects the interest of investors and, accordingly, the dynamic development of tourism.

Dynamics of the indicator of the growth's rate of investment in the tourism industry of the most developing countries indicates the influence of service outsourcing certification of multinational companies.

Thus, it is possible to recommend beginning to the public authorities responsible for development of tourism in developing countries a campaign for outsourcing of foreign services of certification. Here it is possible to face the counterargument connected with economic security of national economies. However our offer concerns only the sphere of voluntary certification which is attractive to investors. Also our recommendations are specified by need of outsourcing of the corresponding services in the course of formation of a national system of certification.

The study of the universal model of financing certification services in the field of tourism has led us to believe that the functions of the basic organization for the control of tourist services are extremely wide. Such a structure in the future will be a factor of increasing bureaucracy and financial losses, which will affect the financial costs and efficiency of the entire financing algorithm. Thus, for an objective assessment of the reliability of accounting activities to use the services of independent consulting companies.

\section{Conclusions}

Based on the results of the study, we can come to the following:

1) Outsourcing of foreign certification services is one of the factors of successful branding of the region.

2) Developing countries do not always have a national certification scheme in place that meets the requirements of foreign investors.

3) With regard to paragraph 2, developing countries are encouraged to use the practice of outsourcing foreign certification services to enhance competition in the domestic market for relevant services.

4) In order to objectively assess the reliability of accounting and reporting, it is advisable to use an external audit of the processes of financing certification programs in the field of tourism, which will be carried out by an independent audit company.

The above conclusions give us the opportunity to formulate the following recommendations to government agencies responsible for the development of tourism in developing countries:

1) To include in strategic programs of development of the sphere of tourism of an action for establishing contacts with the transnational organizations rendering services in certification of tourist services. 
2) In order to avoid threats concerning economic security of the country to use outsourcing of foreign services of certification in the field of tourism only in the sphere of voluntary certification.

3) For the reason set out in paragraph 2, the mandatory certification should remain the prerogative of the state.

4) In the control of financial flows arising in the process of financing certification services in the field of tourism, use outsourcing of consulting firms.

As a result of the research, in response to the questions determined in the research:

What are the financing models of certificate programs? It is seen that the financial support for certificate programs in the tourism sector is mostly provided by the state at the first stage. However, it is seen that it is in the form of investments in the tourism sector, not as direct financing to certification programs.

Are the financing models sufficient? In developed countries, large tourism enterprises can finance themselves. However, it is thought that it would be more appropriate to provide financial support by foreign tourism enterprises in developing countries. In other words, companies in developed countries provide both financial and information support to businesses in developing countries.

\section{References}

Babeshko, L. O., \& Orlova, I. V. (2018). Assessment of The Impact of Investment In Tourism On The Volume of Tourist Flow. In Financial and Economic Tools Used in the World Hospitality Industry (pp. 275-278). CRC Press. https://doi.org/10.1201/9781315148762-52

Dincer, M. Z., Dincer, F. I., \& Ustaoglu, M. (2015). Reel Effective Exchange Rate Volatilities Impact On Tourism Sector In Turkey: An Empirical Analysis of 2003-2014. Procedia Economics and Finance, 23, 1000-1008.https://doi.org/10.1016/S2212-5671(15)00352-4

Dredge, D., \& Jamal, T. (2011). CertificationAndIndicators. Tourism Recreation, 36(3), 203-204. https://doi.org/10.1080/02508281.2011.11081666

Font, X. (2002). Environmental Certification In TourismAndHospitality: Progress, ProcessandProspects. Tourism Management, 23(3), 197-205.https://doi.org/10.1016/S0261-5177(01)00084-X

Gairbekov, M. S., \& Chaplaev, H.G. (2018). The European Proceedings ofSocial\&BehaviouralSciences. A System OfVoluntaryCertification As An Element OfTerritory Branding. Discussion Paper. 2018-11.

Gairbekov, M. S., \& Chaplaev, K. G. (2017). Outsourcing OfForeign Services for Testing, Examination and Certification as a Factor in Increasing the Investment Attractiveness of the Regional Economy. Basic Research, 10(2), 316-322.https://doi.org/10.15405/epsbs.2019.03.02.231

Gladun, E., \& Ivanova, K. (2017). Preservation of Territories and Traditional Activities of the Northern Indigenous Peoples in the Period of The Arctic Industrial Development." The Interconnected Arctic - UARCTIC CONGRESS 2016. Springer, Cham. https://doi.org/10.1007/978-3-319-57532$2 \_14$

Guliyeva, S. (2020). State and Development Trends of Tourism in Spain in Modern Conditions. Economics And Business: Theoryand Practice, (1-1).

Khoshnevis Yazdi, S., \& Khanalizadeh, B. (2017). Air pollution, economic growth and health care expenditure. Economic research - Ekonomskaistraživanja, 30(1), 1181-1190. https://doi.org/10.1080/1331677X.2017.1314823

Krynova, T. G. (2018). Directionsof State Regulation of Development of Tourist Activities in the Russian Federation. In The Market Transformation of The Russian Economy: Problems, Prospects, Ways of Development (pp. 101-104). 
Larionova, A. A. (2013). Formation of Financial Flows in The System of Voluntary Certification of Personnel in Tourism and Service. Finance and Credit, 25(553), 59-64.

Ogneva, S. V. (2013). Certificationoftourismindustrypersonnel. Service in Russia and Abroad, 8(46), 128-135.

Panochkina, K. V. (2016). Metody Antikrizisnogo Upravleniya Pri Prinyatii Resheniy Na Predpriyatiyakh Real'nogo Sektora Ekonomiki [Anti-Crisis Management Methods When Making Decisions at Enterprises of the Real Sector of the Economy]. Natsional 'NYYEIntereysy: Prioritty I Bezopasnost', 2, 57-65.

Punko, I. M., Komarevtseva, N. A., Mosevich, A. Y., \& Chermashentsev, M. A. (2018). Modern Aspects of Certification in Tourism. Tourism and recreation complex in thesystemof regional development Proceedings ofthe VI International Scientific andPractical Conference. Discussion Paper 2018-11. November 2018.

Rome, A., Crabtree, A., Bien, A., Hamele, H., \& Spenceley, A. (2006). Financial sustainability of sustainable tourism certification programs. International Ecotourism Society, 115-122.

Tariq, M. I. (2015). Providing Assurance to Cloud Computing Through ISO 27001 Certification: How Much Cloud is Securd After Implementing Information Security Standards. Createspace, Scotts Valley, CA, USA.

Vetitnev, A. M., \& Savelieva, N. A. (2014). Features of The OrganizationOf Centers for the Assessment and Certification of Qualifications in the Field of Recreation and Sports and Health Tourism. Izvestiya Sochi State University, 1(29), 41-47.

Walas, B., \& Celuch, K. (2014). Certification In Tourism As An Element of Quality Management Theoretical Aspects and Entrepreneurs' Attitudes. International Journal of Business Quantitative Economics and Applied Management Research, 1(2), 62-71.

Yildirgan, R., \& Zengin, B. (2014). Turizm Ürünlerinin Pazarlanmasında Fiziksel Kanıt Stratejileri [Physical Evidence Strategies in Marketing of Tourism Product]. Bilgi Sosyal Bilimler Dergisi, 2, 69-83. 